\title{
Production of Biodiesel from Vegetable Oil Using Microware Irradiation
}

\author{
N. Kapilan
}

\begin{abstract}
The petroleum oil supply crisis, the increase in demand and the price eruption have led to a search for an alternative fuel of bio-origin in India. Among the alternative fuels, biodiesel is considered as a sustainable renewable alternative fuel to fossil diesel. Non-edible jatropha oil has considerable potential for the production of biodiesel in India. The production of biodiesel from jatropha oil using a conventional heating method takes more than $1 \mathrm{~h}$. In this work, microwave irradiation has been used as a source of heat for the transesterification reaction. A domestic microwave oven was modified and used for microwave heating of the reactants. The time taken for biodiesel production using microwave irradiation was 1 min. The fuel property analysis shows that the properties of jatropha oil biodiesel satisfy the biodiesel standards, and are close to the fossil diesel standards. From this work, it is concluded that biodiesel can be produced from vegetable oil using microwave irradiation, with a significant reduction in production time.
\end{abstract}

Keywords: transesterification, jatropha oil, microwave irradiation, biodiesel property.

\section{Biodiesel Production}

\section{$1.1 \quad$ Introduction}

The demand for fossil fuel in the world has been increasing due to industrialization and the increase in the number of automobiles. According to an estimation, world oil resources are judged to be sufficient to meet the projected growth in demand until 2030 [1]. The analysis by Shahriar and Erkan [2] indicates that the fossil fuel reserves depletion time for crude petroluem oil is approximately 35 year. India is the sixth largest energy consumer, and one of the fastest growing energy consumers in the world, with a rapidly growing economy, a rising population, and an expanding number of middle-class consumers [3]. The government of India is seriously concerned about the fluctuations in global oil prices and consequent expenditure on oil imports. India's bio-fuel policy now aims to find ways to limit rising oil imports by promoting the use of bio-fuels as a renewable alternative source for fossil fuels [4]. In recent times there has been greater awareness of biofuels, in particular, biodiesel, and significant attention has been given to the production of biofuels in order to improve the rural economy.

Jatropha curcas belongs to the Euphorbiaceae family, and is a small tree or bush with spreading branches. It grows in a number of climatic zones in tropical and sub-tropical regions of the world, and can be grown in areas of low rainfall ( $250 \mathrm{~mm}$ per year minimum, 900-1200 mm optimal) and in droughtprone areas. It has large green to pale-green leaves, alternate to sub-opposite, three-to-five-lobed with a spiral phyllotaxis, and can attain a height of up to eight or ten meters under favourable conditions. It starts yielding from the second year onwards and continues for 40 years. Generally, fruits are produced in winter when the shrub is leafless. Each inflorescence yields a bunch of approximately 10 or more ovoid fruits. A three, bi-valved cocci is formed after the seeds mature and the fleshy exocarp dries [5-8]. Figure 1 shows the Jatropha and its seeds. The byproduct of oil extraction is seed cake, which contains 24 to $28 \%$ protein on dry basis. The seed cake protein showed most promising results for adhesive and emulsifying properties, which increase the value of the Jatropha. The major fatty acids present in jatropha oil are oleic acid, linoleic acid, and palmitic acid. Jatropha is found in tropical America, Africa and Asia $[9,10]$. In a combustion study of jatropha oil, it is reported that the fatty acid burned in the first step, and glycerol burned in the second step [11].

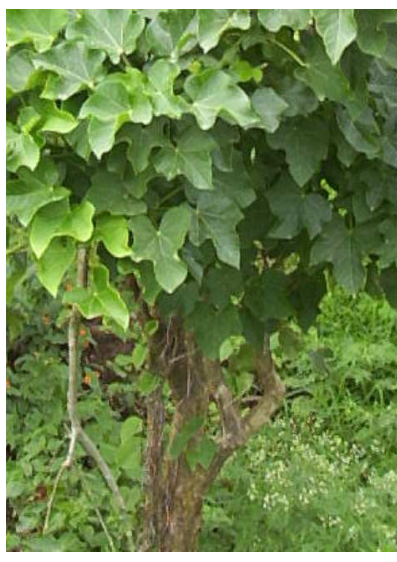

a)

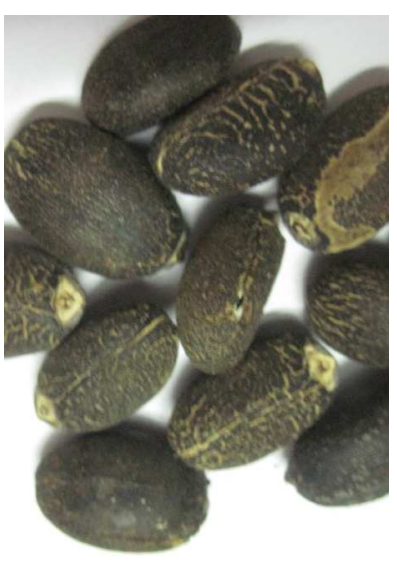

b)
Fig. 1: a) Jatropha, b) Jatropha seeds 
Masami et al. [12] suggested that a domestic biofuel program requires sustained government support, and offer possible justifications for government interventions in the production of biofuel. India is a developing country, and imports more than $70 \%$ of its crude oil from other countries, to meet the local energy demand [13]. In India's bio-fuel policy, Jatropha curcas has been identified as the most suitable plant for the biodiesel production. The government of India encourages the planting of Jatropha in waste and degraded lands, with the aim of rural development and wasteland reclamation [14]. Hence, in this work, jatropha oil was used as the raw material for biodiesel production.

Demirbas [15] reported that vegetable oil, biodiesel, fischer-tropsch and dimethyl ether can be used as a substitute for diesel in diesel engines. However, the direct use of vegetable oil as a substitute for diesel results in higher $\mathrm{CO}, \mathrm{HC}$ and smoke emissions and in lower thermal efficiency of the diesel engine [16]. There are several methods for using vegetable oil as a substitute in diesel engines. One of the most widely used methods is to reduce the viscosity of the vegetable oil by transesterification $[17,18]$. The conventional heating method used in transesterification needs more than one hour reaction time to produce a biodiesel yield of more than $90 \%[19,20]$.

Two-step transesterification is a way of producing biodiesel from crude vegetable oil $[21,22]$. Xin et al [23] used an ultrasonic reactor for the production of biodiesel from jatropha oil, using two-step transesterification. Microwave irradiation has been used for a variety of applications, including organic synthesis. In recent years, microwave irradiation has been used for the production of biodiesel. Yaakob et al. [24] used single-step, base catalyst transesterification for the production of biodiesel from jatropha oil. However, this method required a longer reaction time of $7 \mathrm{~min}$ and a higher catalyst concentration of $4 \%$. In this work, a feasibility study has therefore been carried out to produce biodiesel from jatropha oil using two-step transesterification.

\subsection{Materials}

Jatropha oil was collected from the University of Agricultural Sciences, Bangalore, India. This oil was filtered and used for the production of biodiesel. An alkaline catalyst can be used as an excellent microwave irradiation absorber. In this work, sodium hydroxide was used as a catalyst. In comparison with other alcohols, methanol is cheaper and has better physical and chemical properties (polar and shortest chain alcohol), and it was used as a reactant. Sodium hydroxide, methanol and sulphuric acid were purchased from Merck Company, India. All the chem- icals used for transesterification were of analytical reagent grade.

\subsubsection{Biodiesel production}

Jatropha oil contains an initial acid value of 9 mgKOH per $\mathrm{g}$ of oil, and two-step transesterification was therefore used. In the first step, acid catalyzed transesterfication was used to reduce the acid value from 9 to $1 \mathrm{mgKOH}$ per $\mathrm{g}$ of oil based on the conditions $(0.60 \mathrm{w} / \mathrm{w}$ methanol-to-oil ratio and $1 \% \mathrm{w} / \mathrm{w}$ $\mathrm{H}_{2} \mathrm{SO}_{4}$ ) recommended for the conventional method reported in the literature [22], at a reaction time of $1 \mathrm{~min}$. The experimental setup used in the first step consists of a $250 \mathrm{ml}$ round bottom flask, equipped with a reflux condenser, a mechanical stirrer and a stopper. The scheme is shown in Figure 2. A domestic microwave oven was used for microwave irradiation.

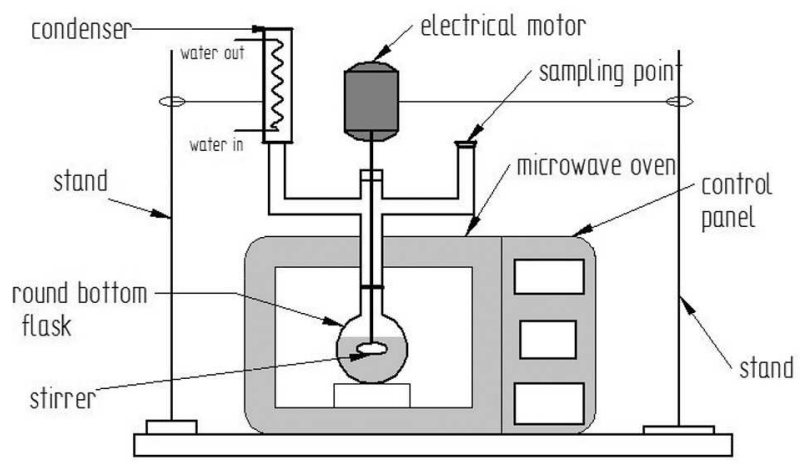

Fig. 2: Microwave-assisted biodiesel production unit

Pre-treated jatropha oil was used in base catalyst second-step transesterification. In the second step, transesterification was carried out at a methanol-tooil ratio of $0.24 \mathrm{w} / \mathrm{w}$ and $1.4 \% \mathrm{w} / \mathrm{w} \mathrm{NaOH}$ [22], with a reaction time of $1 \mathrm{~min}$ and with power supply $100 \mathrm{~W}$. After the reaction, the excess methanol was removed by vacuum distillation and then the transesterification products were poured into a separating funnel for phase separation. After phase separation, the top layer (biodiesel), was separated and washed with distilled water in order to remove the impurities. Then the biodiesel was heated above $100{ }^{\circ} \mathrm{C}$, to remove the moisture. Then the sample was sent for NMR analysis, to find the biodiesel yield. The biodiesel sample was dissolved in chloroform- $d$ $\left(\mathrm{CDCl}_{3}\right)$ and the proton NMR spectra were obtained using a Bruker AMX 400 spectrometer operating at $300 \mathrm{MHz}$.

Experimental errors can arise from the instruments that are used. Uncertainty analysis is therefore needed to prove the accuracy of the experiments. In the present work, uncertainty analysis was performed as per reference [27], and was found to be $\pm 1.5 \%$. 


\subsection{Determination of fuel properties}

The flash point of the biodiesel and diesel were determined as per the ASTM D 93 method. The pour point determinations were made using the ASTM D 97 method. The kinematic viscosity was determined using a viscometer and according to the ASTM D 7042 method. The density of the fuel was determined using a relative density bottle. The calorific value of the fuel was estimated by a bomb calorimeter. The ash content was determined using an electric muffle furnace, and a copper corrosion test was carried out by the copper strip tarnish test, following the ASTM D 130 method. The water content was determined following the ASTM D 95 method. The acid value of the biodiesel was measured following the ASTM D 974 method.

\subsection{Results and discussion}

Biodiesel was produced from jatropha oil by microwave irradiation, and the biodiesel yield was determined using the NMR spectrum. In the NMR spectra, triglycerides (TG) protons on acyl groups resonate at $0.8-2.9 \mathrm{ppm}$, while protons $\mathrm{H}-1, \mathrm{H}-2$ and $\mathrm{H}-3$, appear at a downfield of 4.0-5.6 ppm. When one or two acyl groups migrate from TGs, H-1, H2 and H-3 shift toward a higher field. This is due to loss of the high electron density of the acyl group. Figure 3 shows the NMR spectrum of biodiesel. Compared to the NMR spectrum of jatropha oil, a large signal at $3.6 \mathrm{pm}$ was observed, which was assigned to the methyl protons of the esters. In addition, some new peaks appeared. This was attributed to the methanolysis products of mono and di-glycerides. The conversion of raw oil to biodiesel was calculated on the basis of the references [26]. A higher biodiesel yield was determined and found to be $0.91 \mathrm{~g} / \mathrm{g}$ of jatropha oil. Biodiesel production by microwave irradiation was due to direct adsorption of the radiation by the polar group ( $\mathrm{OH}$ group) of the reactant. It is speculated that the $\mathrm{OH}$ group is directly excited by microwave radiation, and the local tem- perature around the $\mathrm{OH}$ group would be very much higher than its environment. Hence, microwave assisted transesterification is a way of reducing the reaction time, the electrical energy and labour costs as compared to the conventional method. The power consumption in this method was $16.6 \mathrm{~J} / \mathrm{kg}$ of jatropha oil.

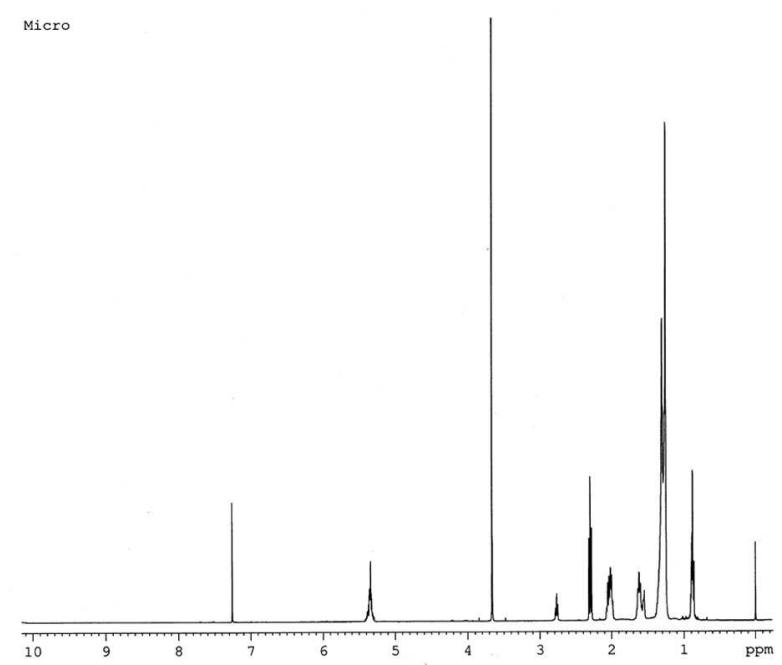

Fig. 3: NMR spectra of biodiesel

Table 1 compares the properties of jatropha biodiesel with the properties of diesel. The flash point of biodiesel satisfies the fuel standards and is better than the flashpoint diesel. This is an important safety consideration when handling and storing flammable materials. The important cold flow properties of biodiesel are the cloud and pour point. According to ASTM standard D 6751, no limit is given for pour point and suggested "report" in the fuel standard. The calorific value is an important property of biodiesel that determines its suitability as an alternative to diesel. In the ASTM and BIS standard, no limit is given for the calorific value. However, in the European standard, EN 14214, the approved calorific value for biodiesel is $35 \mathrm{MJ}$ per $\mathrm{kg}$. The table shows that the calorific value of MOB is close to that of diesel.

Table 1: Fuel properties

\begin{tabular}{|l|c|c|c|}
\hline Property & ASTM D6751 & Biodiesel & Diesel \\
\hline Flash point $\left({ }^{\circ} \mathrm{C}\right)$ & $>130$ & 132 & 68 \\
\hline Pour point $\left({ }^{\circ} \mathrm{C}\right)$ & - & 6 & -15 \\
\hline Calorific Value $(\mathrm{MJ} / \mathrm{kg})$ & - & 37.95 & 42.71 \\
\hline Viscosity at $40^{\circ} \mathrm{C}\left(\mathrm{mm}^{2} / \mathrm{sec}\right)$ & $1.9-6$ & 4.21 & 2.28 \\
\hline Density at $15^{\circ} \mathrm{C}\left(\mathrm{kg} / \mathrm{m}^{3}\right)$ & - & 889 & 846 \\
\hline Water content $(\mathrm{mg} / \mathrm{kg})$ & $<500$ & 129 & 102 \\
\hline Acid number $(\mathrm{mg} \mathrm{KOH} / \mathrm{g})$ & $<0.50$ & 0.42 & 0.34 \\
\hline Copper strip corrosion & $>$ No. 3 & 1 & 1 \\
\hline Ash Content $(\%)$ & $<0.02$ & 0.01 & 0.01 \\
\hline
\end{tabular}


According to the ASTM standards, the acceptable viscosity range for biodiesel is between $1.9-6.0 \mathrm{~mm}^{2} / \mathrm{s}$ at $40^{\circ} \mathrm{C}$, and $\mathrm{MOB}$ satisfies the biodiesel standard. The density of MOB is close to that of diesel and satisfies the BIS standard. The ASTM and BIS biodiesel standard approves a maximum acid value for biodiesel of $0.5 \mathrm{mg} \mathrm{KOH} / \mathrm{g}$, and this was fulfilled by MOB. The degree of tarnish on the corroded copper strip correlates to the overall corrosiveness of the fuel sample. The copper strip corrosion property of MOB is within the specifications of ASTM and BIS. Another important factor of biodiesel is the ash content estimation. The ash content of MOB satisfies both the ASTM standard and the BIS standard.

\section{Conclusions}

In this work, biodiesel was produced from jatropha oil using microwave irradiation and with the help of two-step transesterfication. It was observed that microwave irradiation helps the synthesis of methyl esters (biodiesel) from non-edible oil, and higher biodiesel conversion can be obtained within a few minutes, whereas the conventional heating process takes more than 60 minutes. Biodiesel produced by microwave irradiation satisfies the ASTM and BIS biodiesel standards.

\section{Acknowledgement}

The author wishes to thank Visvesvaraya Technological University, Belgaum, for financially supporting this work (Grant No. VTU/Aca./2009-10/A9/11583, 2009).

\section{References}

[1] Chedid, R., Kobrosly, M., Ghajar, R.: A supply model for crude oil and natural gas in the Middle East, Energy policy, 35, 2007, 2096-2 109.

[2] Shahriar, S., Topal, E.: When will fossil fuel reserves be diminished? Energy Policy, 37, 2009, 181-189.

[3] A report on International Energy Outlook 2008 Report, http://www.eia.doe.gov/oiaf/ieo, http://www.eia.doe.gov/emeu/cabs/India/

Oil.htm (browsed on June, 15, 2010).

[4] Report of the committee on the development of bio-fuel, Planning Commission, Government of India, 2003.

[5] http://en.wikipedia.org/wiki/Jatropha (browsed on June, 15, 2010).
[6] http://www.svlele.com/fattyacids.htm (browsed on June, 15, 2010).

[7] http://www.pia.gov.ph (browsed on June, 15, 2010).

[8] http://www.jatrophabiodiesel.org/ (browsed on June, 15, 2010).

[9] Lestari, D., Mulder, W. J., Sanders, J. P. M.: Jatropha seed protein functional properties for technical applications, Biochemical Engineering Journal, 53, 3, 2001, 297-304.

[10] Hamarneh, A. I., Heeres, H. J., Broekhuis, A. A., Picchioni, F.: Extraction of Jatropha curcas proteins and application in polyketone-based wood adhesives, International Journal of Adhesion and Adhesives, 30, 7, 2010, 615-625.

[11] Wardana, I. N. G.: Combustion characteristics of jatropha oil droplets at various oil temperatures, Fuel, 89, 3, 2010, 659-664.

[12] Kojima, M., Johnson, T.: Biofuels for transport in developing countries: socioeconomic considerations, Energy for Sustainable Development, X, $2,2006$.

[13] Subramanian, K. A., Singal, S. K., Saxena, M., Singhal, S.: Utilization of liquid biofuels in automotive diesel engines: An Indian perspective, Biomass and Bioenergy, 29, 2005, 65-72.

[14] Shanker, A., Fallot, A.: Global Environmental Facility - Scientific and Technical Advisory Panel Workshop on Liquid Biofuels: main findings, Energy for Sustainable Development, 10, $2,2006,19-25$.

[15] Demirbas, A.: Present and Future Transportation Fuels, Energy Sources, Part A, 30, 2008, 1473-1483.

[16] Devan, P. K., Mahalakshmi, N. V.: Performance, emission and combustion characteristics of poon oil and its diesel blends in a DI diesel engine, Fuel, 88, 5, 2009, 861-867.

[17] Marchetti, J. M., Miguel, V. U., Errazu, A. F.: Possible methods for biodiesel production, $J$. Renewable and Sustainable Energy Reviews, 11, 2007 1300-1311.

[18] Ilkılıç, C., Aydın, S., Behcet, R., Aydin, H.: Biodiesel from safflower oil and its application in a diesel engine, Fuel Processing Technology, 92, 3, 2011, 356-362. 
[19] Jain, S., Sharma, M. P.: Biodiesel production from Jatropha curcas oil, Renewable and Sustainable Energy Reviews, 14, 9, 2010, 3140-3147.

[20] Koh, M. Y., Ghazi, T. I. M.: A review of biodiesel production from Jatropha curcas L. oil, Renewable and Sustainable Energy Reviews, 15, 5, 2011, 2240-2 251.

[21] Balat, M.: Production of Biodiesel from Vegetable Oils: A Survey, Energy Sources, Part A: Recovery, Utilization, and Environmental Effects, 29, 2010, 895-913.

[22] Berchmans, H. J., Hirata, S.: Biodiesel production from crude Jatropha curcas L. seed oil with a high content of free fatty acids, Bioresource Technology, 99, 6, 2008, 1716-1 721.

[23] Deng, X., Fang, Z., Liu, Y.: Ultrasonic transesterification of Jatropha curcas L. oil to biodiesel by a two-step process, Energy Conversion and Management, 51, 12, 2010, 2802-2807.

[24] Yaakob, Z., Sukarman, I. S., Kamarudin, S. K., Abdullah, S. R. S., Mohamed, F.: Produc- tion of Biodiesel from Jatropha Curcas by Microwave Irradiation, 2nd WSEAS/IASME International Conference on Renewable Energy Sources (RES'08), Corfu, Greece : October 26-28, 2008.

[25] Chauhan, B. S., Kumar, N., Jun, Y. D., Lee, K. B.: Performance and emission study of preheated Jatropha oil on medium capacity diesel engine, Energy, 35, 6, 2010, 2 484-2 492.

[26] Jin, F., Kawasaki, K., Kishida, H., Tohji, K., Moriya, T., Enomoto, H.: NMR spectroscopic study on methanolysis reaction of vegetable oil, Fuel, 86, 2007, 1201-1207.

[27] Holman, J. P.: Experimental methods for engineers. McGraw Hill,USA, 2006.

Natesan Kapilan

E-mail: kapil_krecmech@yahoo.com

Department of Mechanical Engineering

Nagarjuna College of Engineering and Technology

Devanahalli, Bangalore - 562 110, INDIA 